\title{
P-137ＢP180 は頭頸部扁平上皮癌の予後因子
}

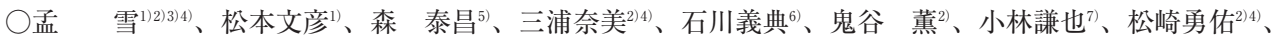 \\ 吉本世一ㄱ․ 池田勝久 ${ }^{1)}$ 、本田一文 ${ }^{24)}$ \\ 順天堂大学 耳鼻咽喉科 ${ }^{1)}$ 、国立がん研究センター研究所＼cjkstart早期診断バイオマーカー開発部門2)、 \\ 中国医科大学付属盛京医院 口腔顎面外科 ${ }^{3)}$ 、日本医科大学大学院 医学研究科 生体機能制御学分野4、 \\ 国立がん研究センター中央病院 病理科 ${ }^{5)}$ 、国立がん研究センター研究所 研究所病理部 6 、 \\ 国立がん研究センター中央病院 頭頸部外科 $7^{7)}$
}

Protein expression of BP180 was verified by immunohistochemistry in a tissue microarray study of 202 cases in Head and neck squamous cell carcinoma. IHC analysis revealed that protein expression of BP180 among HNSCC patients differed significantly in neural invasion, and according to $\mathrm{T}$ status in laryngeal and pharyngeal cancer subgroups. In overall survival analysis and multivariate analysis, we found that positive BP180 IHC and advanced clinical stage were significant independent positive predictors of mortality in HNSCC patients. In addition, in the oral squamous cell carcinoma subgroup, independent positive predictors were positive BP180 IHC, advanced N status and neural invasion. In patients with laryngeal or pharyngeal cancer, predictors were positive BP180 IHC and advanced clinical stage. BP180 is a prognostic factor in head and neck squamous cell carcinoma.

\section{P-138 頭頸部扁平上皮癌における網羅的メタボローム解析}

○大橋敏充、寺澤耕祐、西堀丈純、青木光広、小川武則 岐阜大学 医学部 耳鼻咽喉科

（背景）がん組織の特徴の一つにエネルギー代謝の変化が挙げられ、糖代謝（ワーグブルグ効果）、アミノ酸代謝、脂質代 謝などが、正常細胞と異なることが知られている。(方法) 正常咽頭組織 6 例と頭頸部扁平上皮癌組織14例の糖、アミ) 酸、ヌクレオチドなどのメタボローム解析を質量分析計で網羅的に評価した。(結果) 糖代謝に関しては、グルコースから ピルビン酸までの経路の代謝物の多くは、癌組織で低值であったが、乳酸は高值であった。TCA 回路では、前半のクエン 酸は癌組織で低值であったが、後半のコハク酸は高值であった。アミノ酸代謝に関しては、Ala、Asn、Gly、Ile、Pro、Val では癌組織で高值であり、総アミノ酸量も高值であった。DNA やヒストンのメチル化反応におけるメチル基供与体となる $\mathrm{S}$ アデノシルメチオニンや、がん代謝物として知られる 2 ヒドロキシグルタル酸は、癌組織で高值であった。(結論) 頭頸 部癌組織は正常組織とは、組織内に蓄積した代謝物が異なり、それらの代謝状態の違いを反映していると考えられた。

\section{P-139＼cjkstart水酸化酵素 PLOD2 による Integrin $\beta 1$ 安定化を介した口腔扁平上皮癌浸潤・転移制御機構}

○植木雄志、堀井 新

新潟大学 医学部 耳鼻咽㑨科・頭頸部外科

【背景・目的】癌細胞を取り巻く炎症性サイトカインや低酸素などの腫瘍微小環境は、癌の進展や治療抵抗性に密接に関 与すると考えられる。今回、低酸素応答分子として知られる水酸化酵素 PLOD2 (procollagen-lysine 2-oxoglutarate 5-dioxygenase）の口腔癌の浸潤・転移における機能解析を行った。【方法】ヒト由来口腔扁平上皮がん細胞株を用いて、PLOD2 発 現抑制／強制発現による浸潤能の変化を scratch assayにより評価した。さらに、PLOD2 依存性に発現が变化する分子を PCR、ウェスタンブロット等で検討し、PLOD2による浸潤能制御の分子基盤を解析した。【結果】口腔癌細胞の浸潤能は PLOD2 発現依存性に変化した。さらに、PLOD2 による浸潤能は癌の浸潤・転移に重要な分子として知られる Integrin $\beta 1 の$ 細胞膜上への発現安定化によって制御されていることが明らかとなった。【結語】水酸化酵素 PLOD2 によるIntegrin $\beta 1$ 安 定化を介した口腔癌浸潤・転移制御機構はこれまでに知られていなかった新規分子基盤であり、新たな治療標的となる可能 性が示唆された。

\section{P-140 HPV 関連頭頸部癌における標的分子の探索}

○近藤俊輔、池上太郎、鈴木幹男

琉球大学 耳鼻咽喉科

腫瘍増殖と mTOR(mechanistic target of rapamycin) との関連は多く報告されている。しかし HPV 関連癌との関連につ いての報告は多くない。本報告では HPV 関連癌と mTOR 経路との関連について癌細胞株および中咽頭癌組織で検討した結 果を報告する。癌細胞株では高リスク型 HPV 陽性癌細胞株では高リスク型 HPV 陰性癌細胞株と比較し mTORの複合体に 含まれる Raptorの発現が上昇していた。また mTORの阻害剤であるテムシロリムス投与により、高リスク型 HPV 陽性癌 細胞株は陰性癌細胞株と比較し細胞增殖が抑えられた。さらに中咽頭癌組織においても HPV 関連中咽頭癌では非関連癌と 比較し Raptor および Rictorの発現が上昇していた。また Raptor および Rictorの高発現群では低発現群と比較し予後が不良 であった。以上の結果から HPV 関連頭頸部癌において mTOR 複合体に含まれる、Raptor および Rictor が増殖において重 要な役割を果たしており、HPV 関連癌における治療のターゲットとなる可能性が示唆された。 
P-141 ナノスーツ法を用いた頭頸部乳頭腫組織の検討

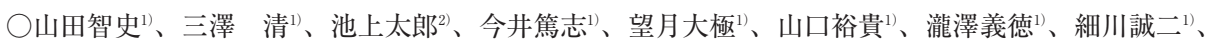

鈴木幹男 ${ }^{2)}$ 、峯田周幸 ${ }^{11}$

浜松医科大学 耳鼻咽喉科・頭頸部外科 ${ }^{12}$ 、琉球大学 耳鼻咽喉・頭頸部外科 ${ }^{2}$

くはじめに>ナノスーツ法は、高真空が必要な電界放出型走査型電子顕微鏡（FE-SEM）で八工の幼虫が生きたまま観察 できることに着想を得た、バイオミメティクス技術である。光学顕微鏡で観察した病理スライドを構造変化なく、簡便に FE-SEM で観察可能である。

<対象・方法＞喉頭乳頭腫17例34検体、中咽頭乳頭腫10例11検体を対象とした。組織より DNAを抽出しPCR 法にて HPV の関与を検討した。p16、YAP（Hippo 経路のキー蛋白)、L1（HPVのカプシド蛋白）の免疫染色を行い、経時的な変 化を検討した。L1 陽性例はナノスーツ法を用い、FE-SEM で観察した。

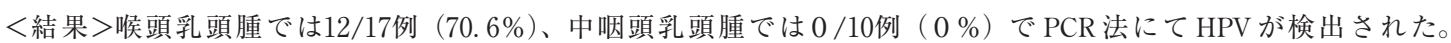
p16、YAP、L1 の免疫染色は喉頭乳頭腫で手術回数と染色性に弱い負の相関を認めたが、中咽頭乳頭腫では一定の傾向はな かった。L1 陽性部はナノスーツ法を用いた FE-SEM で HPV 粒子様構造を認めた。

くまとめ>乳頭腫は部位で成因が異なると予想される。喉頭乳頭腫は加療を行うことで HPV 粒子数が減少し寛解状態に 向かう可能性がある。

\section{P-142ＨPV 関連頭頸部癌に対する Cannabidiol(CBD) の作用}

○戎本浩史 ${ }^{1)}$ 、酒井昭博1)、大上研二 ${ }^{11}$ 、Joseph Califano $0^{2)}$

東海大学 医学部 耳鼻咽喉科 ${ }^{11}$ 、UC San Diego, Moores Cancer Center ${ }^{2}$

米国においては、90年代後半以降、医療用を皮切りに、嗜好用大麻の合法化が各州に広がっており、本邦においても一部 に大麻合法化を目指す動きがある。大麻の薬効成分である Cannabinoidには、鎮痛・鎮静作用、抗炎症作用のほか、抗腫瘍 効果も報告され、新たな抗癌剤・治療補助剂としての役割も期待されている。ところが、HPV 関連頭頸部に対しては、大 麻の常用が独立した危険因子である。Cannabinoidのうち、精神依存性を持つ $\Delta$ 9-Tetrahydrocannabinol(THC) は、 Cannabinoid receptor を介してp38MAPK 経路を刺激し、腫瘍増殖にはたらく。今回、ほかの代表的な Cannabinoidであ り、精神依存性を持たない Cannabidiol(CBD) の HPV 関連頭頸部癌に対する作用について研究を行った。CBD は乳癌や肺 癌等、複数の癌腫で抗腫瘍効果が報告されているが、HPV 関連頭頸部癌細胞株では Erk1/2 と p38MAPK を活性化させ、腫 瘍を増殖させた。また、CBD は放射線治療による apoptosis を抑制した。頭頸部癌に対してはほかの癌腫と異なる作用機序 の存在も推定され、その解明が今後の課題である。

\section{$\mathrm{P}-143$ 当院で診断に難渋した喉頭クリプトコッカス症の 1 例}

○東内和也、西尾直樹、横井紗矢香、鈴木克尚、小林万純、向山宣昭、平松真理子、丸尾貴志、曾根三千彦 名古屋大学 医学部

【主訴】咽頭痛、嗄声【既往歴】気管支喘息、関節リウマチ【内服薬】プレドニゾロン $5 \mathrm{mg}$ 、メトトレキサート $6 \mathrm{mg} 、 フ ゙$ テゾニドホルモテロールフマル酸【現病歴】56歳女性。2 月下旬に咽頭痛、嗄声を自覚した。近医受診しても改善なく市中 病院に紹介受診となった。生検施行するも確定診断に至らず経過観察となった。6月咽頭痛、咳嗽症状が強くなり当科に紹 介受診となった。【臨床経過】内視鏡下生検では悪性像は認めなかったが、全身麻酔下喉頭微細手術による生検で喉頭原発 のクリプトコッカス症と診断に至った。その後フルコナゾール 400mg/日（3～12カ月）の治療を開始した。内服開始後速 やかに白苔病変は縮小し、治療開始 6 週後には咽頭痛、嗄声共に改善した。【考察】喉頭原発の病変は非常にまれで報告さ れている症例は国内で 5 例、海外で28例のみである。生検しても確定診断に至らないこともあり、病理医との連携が重要で ある。【結語】当院で診断に難渋し、喉頭微細手術による生検で診断された喉頭クリプトコッカスの症例を経験した。

\section{P-144Ｓaccular cyst と鑑別を要した鰓裂囊胞の 2 例}

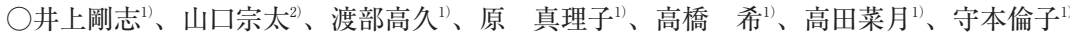
成育医療研究センター 耳鼻咽喉科 ${ }^{1)}$ 、東邦大学医療センター大橋病院 ${ }^{2}$

小児の喉頭に囊胞があると気道狭窄を来し、早急に対応しなければならないことが少なくない。今回われわれは気道狭窄 を来し緊急手術が必要となった喉頭囊胞を 2 例経験した。症例 1 は、 2 カ月男児。喘鳴、左頸部腫脹を主訴に受診し左頸部 から喉頭に広がる $28 \times 25 \times 25 \mathrm{~mm}$ の喉頭を圧迫する囊胞性病変を認め、緊急で開密術を行い呼吸困難は改善した。しか し、その後も感染増大を繰り返しその度に霬胞穿刺を行った。1歳 5 カ月時に、Saccular cyst 混合型の疑いで頸部外切開で 摘出し、舌骨下部を通って咽頭内に至る鰓裂囊胞と判明した。症例 2 は、 1 歳 7 カ月の男児。右頸部腫脹と陥没呼吸を主訴 に受診し、右頸部から喉頭にかけて $24 \times 38 \times 27 \mathrm{~mm}$ ダンベル型の囊胞性病変を認め当科に紹介となった。開空術および $\mathrm{CO}$ 2 レーザーによる焼灼術を施行した。その後、病変が再度徐々に増大してきたため、外切開により摘出術を行い舌骨下方を 通り咽頭腔に至る鰓裂囊胞と判明した。小児の喉頭を圧排する囊胞性疾患の病理、手術所見等について考察する。 